\title{
Effect of cooling during the dry period on immune response after Streptococcus uberis intramammary infection challenge of dairy cows
}

\author{
I. M. T. Thompson, S. Tao, A. P. A. Monteiro, K. C. Jeong, and G. E. Dahl' \\ Department of Animal Sciences, University of Florida, Gainesville 32611
}

\begin{abstract}
Heat stress in the dry period affects the immune status of dairy cows in the subsequent lactation. We hypothesized that cooling during the dry period improves immune response to postpartum intramammary infection (IMI) by environmental pathogens such as Streptococcus uberis. Cows were dried off $46 \mathrm{~d}$ before expected calving and assigned to cooling $(\mathrm{CL}, \mathrm{n}=15)$ or heat stress $(\mathrm{HT}, \mathrm{n}=15)$. Cooled cows were housed with sprinklers, fans, and shade, whereas the HT group had only shade. All cows were cooled postpartum. Rectal temperature $(\mathrm{RT})$ and respiration rate $(\mathrm{RR})$ were recorded thrice weekly during the dry period. From -46 to 42 d relative to calving, dry matter intake was recorded daily, and both body weight (BW) and body condition score (BCS) weekly. Milk yield and composition were recorded daily after calving. Streptococcus uberis IMI was induced at $5 \mathrm{~d}$ postpartum in a subset of cows (CL, $\mathrm{n}=5 ; \mathrm{HT}, \mathrm{n}=5$ ). Blood was collected at $0,12,18,24$, and $36 \mathrm{~h}$ after IMI. Hematological analysis was performed, and neutrophils isolated for RNA extraction. Immune response genes (TLR2, IL1- $\beta$, $I L 6, I L 8, I L 10$, and $T N F \alpha$ ) were assessed by real-time, reverse transcription-PCR. Relative to HT cows, CL cows had lower RT and RR during the dry period. The CL cows also consumed more feed prepartum but not postpartum, gained more BW prepartum but lost more BW in lactation, and had higher BCS score prepartum and a lower BCS postpartum. During $40 \mathrm{wk}$ of lactation, CL cows produced more milk (33.8 vs. 30.0 $\mathrm{kg} / \mathrm{d}$ ) than HT cows but milk composition was not affected. Cows in the CL group had greater white blood cell counts and more neutrophils than HT cows during IMI. From 0 to $36 \mathrm{~h}$ post-IMI, TNF $\alpha$ mRNA expression decreased, whereas that of $I L 6$ and IL8 increased in both treatments. Additionally, CL cows had lower IL10 mRNA expression at $18 \mathrm{~h}$ post-IMI. Expression of TLR2 mRNA decreased over time in both treatments. However, CL cows had greater overall TLR2 mRNA expression than HT. No differences were detected for
\end{abstract}

Received October 18, 2013.

Accepted September 19, 2014.

${ }^{1}$ Corresponding author: gdahl@ufl.edu
mRNA expression of IL1- $\beta, I L 6, I L 8$, or TNF . Cooling cows during the dry period alters immune function and neutrophil response to IMI in early lactation.

Key words: heat stress, neutrophil, intramammary infection

\section{INTRODUCTION}

Heat stress has detrimental effects on milk production, reproductive performance, and immune status of dairy cows during lactation (Hahn, 1999; Kadzere et al., 2002; Collier et al., 2006). In addition, exposure of cows to heat stress during the dry period compromises mammary cell proliferation when the cows are dry (Tao et al., 2011) and affects milk production in the subsequent lactation (do Amaral et al., 2009, 2011; Tao et al., 2011). Moreover, dry period heat stress affects early lactation immune response by decreasing lymphocyte proliferation (do Amaral et al., 2010) and neutrophil phagocytosis and oxidative burst (do Amaral et al., 2011). Furthermore, increased incidence of postpartum disorders, such as retained placenta and mastitis, has been associated with exposure of cows to high temperatures during the dry period (Thompson and Dahl, 2012).

Mastitis is a highly prevalent inflammatory disease that affects the mammary gland of dairy cows most frequently during early lactation (Vangroenweghe et al., 2005). Many bacterial pathogens are capable of causing mastitis. Streptococcus uberis is one of the most prevalent environmental pathogens associated with the occurrence of both subclinical and clinical IMI (Jayarao et al., 1999; Phuektes et al., 2001). Little is known about the effect of exposure of cows to heat stress during the dry period on postpartum immune responses to IMI. Therefore, we hypothesized that cooling cows during the dry period improves immune response to postpartum IMI to environmental pathogens such as Streptococcus uberis.

\section{MATERIALS AND METHODS}

\section{Animal and Experimental Design}

The experiment was conducted at the University of Florida Dairy Unit (Hague), from June to October 2011. Animal handling and experimental procedures were ap- 
proved by the Institutional Animal Care and Use Committee of the University of Florida. Approximately $46 \mathrm{~d}$ before expected calving, 30 multiparous Holstein cows were dried off and randomly assigned to 2 treatments: heat stress $(\mathbf{H T}, \mathrm{n}=15)$ and cooling $(\mathbf{C L}, \mathrm{n}=15)$, based on mature-equivalent milk production of the previous lactation. That value was then used as a covariate in the statistical analyses of milk production. During the dry period, cows were housed in a freestall barn with a cooling system for CL cows consisting of shade, sprinklers, and fans, whereas HT cows were provided only shade. Fans ran continuously, whereas sprinklers turned on automatically for $1.5 \mathrm{~min}$ at 6 -min intervals when the ambient temperature exceeded $23.9^{\circ} \mathrm{C}$. In the dry cow barn, photoperiod (14 h light and $10 \mathrm{~h}$ dark) was controlled by metal halide lights to approximately $600 \mathrm{~lx}$ intensity at the eye level of the cows. The lights were kept on from 0600 to $2000 \mathrm{~h}$. After calving, cows from both treatments were housed in the same freestall barn, cooled by sprinklers and fans, and exposed to the same photoperiod. Hobo Pro Series Temp probes (Onset Computer Corp., Pocasset, MA) were placed approximately in the center of each pen, under shade, and were used to measure air temperature and relative humidity of the stalls every $15 \mathrm{~min}$. Temperature-humidity index (THI) was calculated based on the following equation described by Dikmen et al. (2008): THI $=(1.8 \times \mathrm{T}+$ $32)-[(0.55-0.0055 \times \mathrm{RH}) \times(1.8 \times \mathrm{T}-26)]$, where $\mathrm{T}=$ air temperature $\left({ }^{\circ} \mathrm{C}\right)$ and $\mathrm{RH}=$ relative humidity (\%). Rectal temperature (RT) was measured twice daily (0730 and $1430 \mathrm{~h}$ ) by using a GLA M700 digital thermometer (GLA Agricultural Electronics, San Luis Obispo, CA). Dry period respiration rate $(\mathbf{R R})$ was counted thrice weekly (1500 h on Monday, Wednesday, and Friday). Body weight was recorded and BCS estimated for each cow once weekly from dry off until 42 d postpartum. Lactating cows were milked twice daily (0800 and $2000 \mathrm{~h}$ ), and daily milk production and milk composition were recorded by the AfiLab milk analyzer (Kibbutz Afikim, Israel) at each milking until $42 \mathrm{wk}$ postpartum. Dry cows were fed once a day $(0800 \mathrm{~h})$, and lactating cows were fed twice daily (0730 and 1300 h). Daily DMI was measured from dryoff until $42 \mathrm{~d}$ postpartum. The composition of diets for dry and milking cows is given in Table 1 .

\section{Streptococcus uberis Intramammary Challenge}

Streptococcus uberis IMI was induced at 5 d postpartum in a subset of cows of each treatment (CL, n = 5 ; HT, $\mathrm{n}=5$ ). In cows enrolled in the challenge, each of the 4 individual quarters had milk SCC $<200,000$ cells/mL, which was measured for 6 milkings before the beginning of the challenge. Streptococcus uberis
Table 1. Ingredient composition of TMR fed to cows cooled or under heat stress during the dry period during prepartum and postpartum periods

\begin{tabular}{|c|c|c|}
\hline $\begin{array}{l}\text { Ingredient } \\
\text { ( } \% \text { of DM) }\end{array}$ & Prepartum & Postpartum \\
\hline Corn silage & 47.30 & 21.60 \\
\hline Alfalfa hay & - & 9.00 \\
\hline Wet brewers grain & 13.60 & 11.00 \\
\hline Rye silage & 22.70 & 9.00 \\
\hline Soy hulls & - & 5.43 \\
\hline Corn meal & 4.60 & 21.98 \\
\hline Soybean meal & - & 4.54 \\
\hline Whole cotton seed & - & 6.32 \\
\hline Citrus pulp & - & 4.44 \\
\hline Soy Plus ${ }^{1}$ & 6.80 & 3.06 \\
\hline Mineral and vitamin $\operatorname{mix}^{2}$ & 5.00 & 3.60 \\
\hline
\end{tabular}

${ }^{1}$ West Central Cooperative (Ralston, IA).

${ }^{2}$ Mineral and vitamin mix prepartum included $21 \% \mathrm{CP}, 2 \%$ crude fat, $13 \%$ crude fiber, $8.5 \% \mathrm{Ca}, 1 \% \mathrm{P}, 3 \% \mathrm{NaCl}, 3.5 \% \mathrm{Mg}, 4.4 \% \mathrm{~S}, 34 \mathrm{mg} /$ $\mathrm{kg}$ of $\mathrm{Co}, 129 \mathrm{mg} / \mathrm{kg}$ of Cu, $15 \mathrm{mg} / \mathrm{kg}$ of I, $300 \mathrm{mg} / \mathrm{kg}$ of $\mathrm{Mn}, 7 \mathrm{mg} /$ $\mathrm{kg}$ of Se, $435 \mathrm{mg} / \mathrm{kg}$ of Zn, $200 \mathrm{mg} / \mathrm{kg}$ of F, 220,459 IU of vitamin A/ $\mathrm{kg}, 70,000 \mathrm{IU}$ of vitamin $\mathrm{D}_{3} / \mathrm{kg}, 5,512 \mathrm{IU}$ of vitamin $\mathrm{E} / \mathrm{kg}$. Mineral and vitamin mix postpartum included $25 \% \mathrm{CP}, 0.25 \%$ crude fat, $1 \%$ crude fiber, $3 \% \mathrm{ADF}, 5.75 \% \mathrm{Ca}, 1.2 \% \mathrm{P}, 4.75 \% \mathrm{NaCl}, 9.25 \mathrm{mg} / \mathrm{kg}$ of Se, $110,230 \mathrm{IU}$ of vitamin $\mathrm{A} / \mathrm{kg}, 39,683 \mathrm{IU}$ of vitamin $\mathrm{D}_{3} / \mathrm{kg}, 1,102 \mathrm{IU}$ of vitamin $\mathrm{E} / \mathrm{kg}, 381 \mathrm{mg} / \mathrm{kg}$ of monensin.

(NIRD-0140J strain) was generously provided by Stephen Nickerson (University of Georgia, Athens); it was cultured overnight $(18 \mathrm{~h})$ at $37^{\circ} \mathrm{C}$ in trypticase soy broth (Difco, Detroit, MI). The overnight culture was diluted in sterile saline $(0.9 \% \mathrm{NaCl})$ to obtain an optical density at $600 \mathrm{~nm}\left(\mathbf{O D}_{600}\right)$ of 1.0 using a spectrophotometer. Those cells were further diluted using a 10 -fold serial dilution to obtain an inoculum of $10^{3} \mathrm{cfu} /$ $\mathrm{mL}$ in sterile saline. One hundred microliters of each serially diluted bacterial culture was plated on tryptic soy agar plates, and plates were incubated overnight at $37^{\circ} \mathrm{C}$ to enumerate the exact number of bacteria used for the Strep. uberis challenge. After the nighttime milking, cows from both treatments (i.e., CL and HT) were moved to a hospital barn for the Strep. uberis challenge. Before inoculation, challenged teats were cleaned with $70 \%$ isopropyl alcohol pads. Following the cleaning procedure, $1 \mathrm{~mL}$ of inoculum containing Strep. uberis was infused into one rear quarter and $1 \mathrm{~mL}$ of sterile saline solution was infused into the other rear quarter of each cow by using a sterile disposable syringe fitted with a plastic disposable teat cannula (Jorgensen Laboratories, Loveland, CO). Immediately following inoculation, all teats were immersed in a teat disinfectant containing 1\% iodine. At $36 \mathrm{~h}$ postinoculation, after all samples were collected, cows were milked and Strep. uberis-infected quarters were treated with a daily infusion of $125 \mathrm{mg}$ of ceftiofur $\mathrm{HCl}$ (SpectraMast LC, Pfizer Animal Health, Kalamazoo, MI) for 7 consecutive days.

Body temperature and RR were recorded at 0,12 , 18,24 , and $36 \mathrm{~h}$ relative to the IMI. Additionally, blood 
samples $(7 \mathrm{~mL})$ for hematology analyses were collected from coccygeal vessels into $\mathrm{K}_{3}$ EDTA Vacutainer tubes (Becton Dickinson, Franklin Lakes, NJ) at 0, 12, 18, 24 , and $36 \mathrm{~h}$ relative to the IMI. Hematology analyses were performed at the University of Florida Veterinary Medical Teaching Hospital (Gainesville). Milk samples were collected using bronopol B-14 as a preservative at $0,12,18,24$, and $36 \mathrm{~h}$ relative to the IMI. Samples were analyzed for fat, protein, lactose, and SCC by Southeast Milk Inc. Laboratory (Belleview, FL). Moreover, during the challenge, milk production was recorded by the AfiLab milk analyzer (Kibbutz Afikim, Israel) after each milking (i.e., at 12,24 , and $36 \mathrm{~h}$ relative to IMI).

\section{RNA Extraction and Quantitative Reverse-Transcription PCR Analyses}

The abundance of $I L 1-\beta$ (bovine interleukin 1- $\beta$ : NM_174093.1), IL10 (bovine interleukin 10: NM_174088.1), TNF $\alpha$ (bovine tumor necrosis factor $\alpha$ : NM_173966.3), IL8 (bovine interleukin 8: NM_173925.2), IL6 (bovine interleukin 6: NM_173923.2), and TLR-2 (bovine toll-like receptor 2: EU746459.1) transcripts in bovine neutrophils isolated from blood samples at $0,12,18,24$, and $36 \mathrm{~h}$ relative to Strep. uberis IMI were determined by quantitative (q)PCR. Gene-specific primer sets for $I L 1-\beta$, IL10, TNF $\alpha$, IL8, IL6, TLR-2, and GAPDH genes were designed (Table 2), and GAPDH was used as the reference gene. Total RNA was extracted from neutrophils using Tri reagent (Sigma-Aldrich, St. Louis, MO) with the PureLink RNA Mini kit, according to instructions provided by the manufacturer (Invitrogen, Carlsbad, CA). Subsequently, concentration and purity of isolated RNA were assessed using a NanoDrop 2000 spectrophotometer (Thermo Scientific, Rockford, IL). All samples were incubated with DNase (Applied Biosystems, Foster City, CA) for $30 \mathrm{~min}$ at $37^{\circ} \mathrm{C}$ to remove genomic DNA, and subsequently heat denatured at $75^{\circ} \mathrm{C}$ for $15 \mathrm{~min}$. Total RNA (250 ng/reaction) was reverse transcribed to complementary DNA using the HighCapacity cDNA Reverse Transcription Kit (Applied Biosystems) following the manufacturer's instructions. Standard curves generated from serial dilutions of bovine liver RNA were used to validate the amplification efficiency. In addition, a dissociation curve analysis (60 to $95^{\circ} \mathrm{C}$ ) was used to verify amplification of a single product. Quantitative PCR was completed with SYBR Green as the indicator and the ABI 7300 Real Time PCR System (Applied Biosystems). Amplification of specific genes was obtained by running a mixture of $2.5 \mu \mathrm{L}$ of the cDNA product for each specific primer (IL1- $\beta, I L 10, T N F \alpha, I L 8, I L 6, T L R-2$, or GAPDH) and $22.5 \mu \mathrm{L}$ of SYBR Green PCR Master Mix (Applied
Biosystems) in the reaction. Triplicate reactions were completed for each sample, and a fourth reaction containing RNA sample not exposed to reverse transcriptase was included as a negative control. After an initial activation-denaturation step $\left(60^{\circ} \mathrm{C}\right.$ for $2 \mathrm{~min} ; 95^{\circ} \mathrm{C}$ for $10 \mathrm{~min}), 40$ cycles of a 2 -step amplification protocol $\left(95^{\circ} \mathrm{C}\right.$ for $15 \mathrm{~s}$ and $60^{\circ} \mathrm{C}$ for $\left.1 \mathrm{~min}\right)$ were completed. The abundances of IL1- $\beta, I L 10, T N F \alpha, I L 8, I L 6$, and TLR2 mRNA were calculated relative to $G A P D H$ mRNA (endogenous control) using the following formula: $2^{-\mathrm{Ct}}$ (target gene) $/ 2^{-\mathrm{Ct}(G A P D H)}$ where $\mathrm{Ct}$ is the cycle threshold (Thompson et al., 2011).

\section{Statistical Analyses}

Dry period and gestation length for each treatment were analyzed by the general linear model (PROC GLM) of SAS version 9.2 (SAS Institute Inc., Cary, $\mathrm{NC})$. Rectal temperature, RR, milk production, milk composition, DMI, BW, BCS, and hematology results were analyzed using repeated-measures analyses of the mixed model procedure (PROC MIXED; SAS Institute Inc.). The model included fixed effects of treatment, time, and treatment by time with cow as the random effect. For milk production analyses, mature-equivalent yield in the previous lactation was used as a covariate. In addition, BW and BCS at dryoff and calving were used as covariates for the statistical analysis of BW and BCS during the pre- and postpartum periods, respectively. To separate treatment (i.e., prepartum) and posttreatment (i.e., postpartum) effects, data from $\mathrm{cu}-$ mulative BW, BCS, and DMI were split into prepartum and postpartum periods and analyzed separately. The mean and standard deviation of THI were calculated by PROC UNIVARIATE of SAS.

Analyses of qPCR were completed by ANOVA using the PROC GLM procedure of SAS. Differences in mean values were obtained from comparison of least squares means by the PDIFF option of PROC GLM, which provides a table of $P$-values for all possible pairwise comparisons. Data had a normal distribution and variance within each population was the same.

\section{RESULTS}

\section{$R R, R T, T H I$, and Dry Period and Gestation Lengths}

The THI measurements of the stall areas were similar between CL and HT cows $(78.2 \pm 0.16$ vs $77.9 \pm$ 0.16 ; Table 3 ), indicating that both groups of cows were exposed to similar thermal environmental conditions during the dry period. However, relative to HT cows, CL cows had $0.3^{\circ} \mathrm{C}$ lower RT in the morning $(P=0.01$; Table 3$)$ and $0.5^{\circ} \mathrm{C}$ lower in the afternoon $(P<0.01$; 
Table 2. Genes evaluated by reverse-transcription PCR and their primer sequences

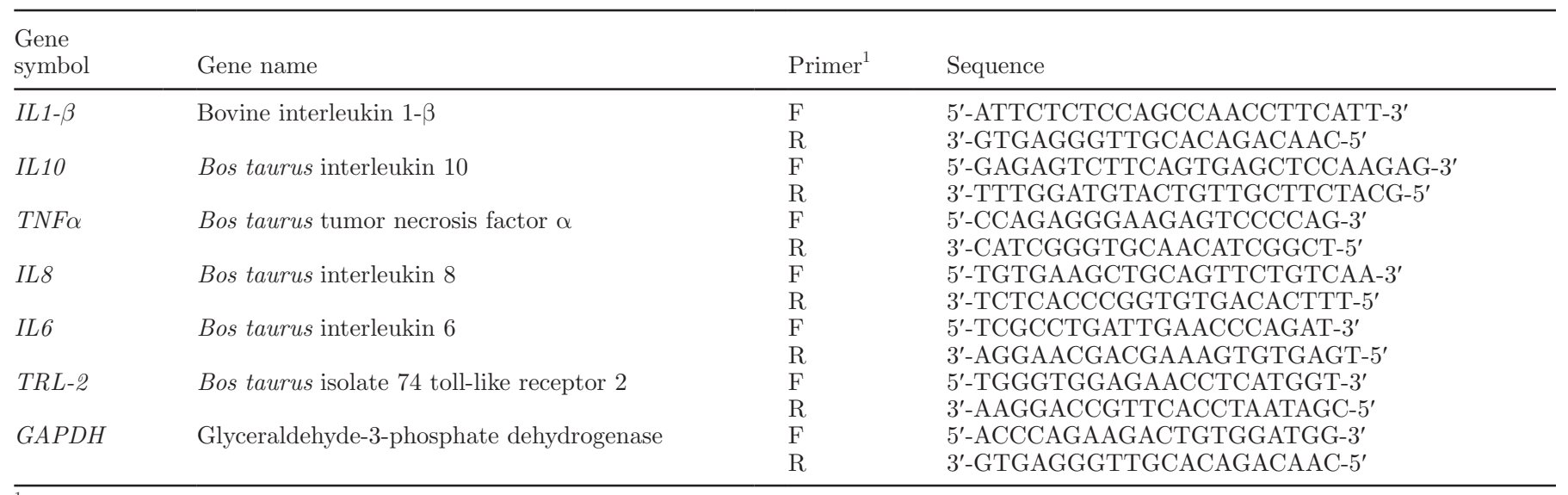

${ }^{1} \mathrm{~F}=$ forward; $\mathrm{R}=$ reverse.

Table 3). Additionally, during the dry period, CL cows had lower RR $(45.0 \pm 2.27$ vs. $78.7 \pm 2.36$ breaths per min; $P<0.01$; Table 3) compared with HT cows. Moreover, the dry period length of CL cows was $5 \mathrm{~d}$ longer $(P=0.01$; Table 3$)$ than that of HT cows, which resulted in a 6 -d increase in gestation length for CL cows $(P<0.01$; Table 3$)$.

\section{Milk Yield, Composition, and Quality}

Cows exposed to cooling during the dry period had a trend for a difference in milk yield. They produced $3.8 \mathrm{~kg} / \mathrm{d}$ more milk $(P=0.10$; Figure 1$)$ until $40 \mathrm{wk}$ postpartum compared with HT cows. We observed no differences between treatments for concentrations of milk fat, protein, and lactose $(P=0.71, P=0.17$, and $P=0.66$, respectively). Furthermore, no treatment effect was observed on SCC $(P=0.79)$.

\section{$B W, B C S$, and DMI}

Body weight did not differ between treatments at dry off $(695.2 \pm 20.0$ vs. $721.0 \pm 20.0 \mathrm{~kg}$ for CL and HT cows respectively; $P=0.37$ ); however, compared with HT, cows exposed to cooling during the dry period gained $42.4 \pm 6.0$ vs $13.4 \pm 6.1 \mathrm{~kg}$ before calving $(P$ $=0.01$; Figure 2$)$. No difference in BW was observed between treatments at calving $(711.42 \pm 6.9$ vs. 678.04 $\pm 7.1 \mathrm{~kg}$ for CL and HT cows, respectively; $P=0.49$ ); however, CL cows had a greater BW loss in early lactation compared with HT cows $(90.4 \pm 7.9$ vs. $34.0 \pm 7.7$ $\mathrm{kg}$ for CL and HT cows respectively; $P=0.05$; Figure $2)$. No differences in BCS were observed at dry off (3.42 \pm 0.12 vs. $3.46 \pm 0.12$ for CL and HT cows respectively; $P=0.82)$; however, CL cows had a greater increase (0.22 units) in BCS prepartum $(P=0.01$; Figure 3$)$. In addition, CL cows tended to have a greater decrease (0.09 units) in BCS ( $P=0.10$; Figure 3$)$ postpartum compared with HT cows. Furthermore, relative to HT cows, CL cows consumed more feed prepartum (12.3 \pm 0.46 vs. $10.4 \pm 0.46 \mathrm{~kg} / \mathrm{d} ; P<0.01$, Figure 4$)$. No differences in DMI were observed between treatments during the postpartum period $(19.0 \pm 1.78$ vs. $19.4 \pm$ $1.77 \mathrm{~kg} / \mathrm{d} ; P=0.82$, Figure 4$)$.

\section{Streptococcus uberis Intramammary Challenge}

Results of statistical analyses of RT, RR, and gestation length of the subgroup of cows $(\mathrm{n}=10)$ enrolled in the Strep. uberis IMI challenge showed differences between cows exposed to CL and HT during the dry period. Relative to HT cows, CL cows enrolled in the Strep. uberis challenge had decreased RT during the dry period in the morning and afternoon (Table 3 ). In addition, CL cows had decreased RR (Table 3) and tended to have increased gestation length compared with HT cows (Table 3). Body weight did not differ between treatments for cows enrolled in the Strep. uberis challenge at dry off $(662.2 \pm 21.4$ vs. $690.5 \pm 21.5 \mathrm{~kg}$ for CL and HT cows, respectively; $P=0.14$ ); however, compared with HT cows, the CL cows gained $37.6 \pm$ 6.5 vs. $23.1 \pm 6.1 \mathrm{~kg}$ before calving $(P=0.02)$. No difference in $\mathrm{BW}$ was observed between treatments at calving $(664.1 \pm 26.9$ vs. $660.3 \pm 27.1 \mathrm{~kg}$ for CL and HT cows, respectively; $P=0.93$ ), and no difference in BW loss in early lactation was observed between treatments $(P=0.33)$. Cows exposed to cooling during the dry period in the challenge subgroup had a trend for a difference in milk yield. They produced $3.5 \mathrm{~kg} / \mathrm{d}$ more milk $(P=0.12)$ until 40 wk postpartum compared with HT cows.

Independent of treatment, RT $(P<0.01)$ and RR $(P<0.01)$ were elevated from 12 to $36 \mathrm{~h}$ compared with $0 \mathrm{~h}$ in response to the Strep. uberis IMI. Additionally, overall milk production decreased $(P<0.01)$ at 24 


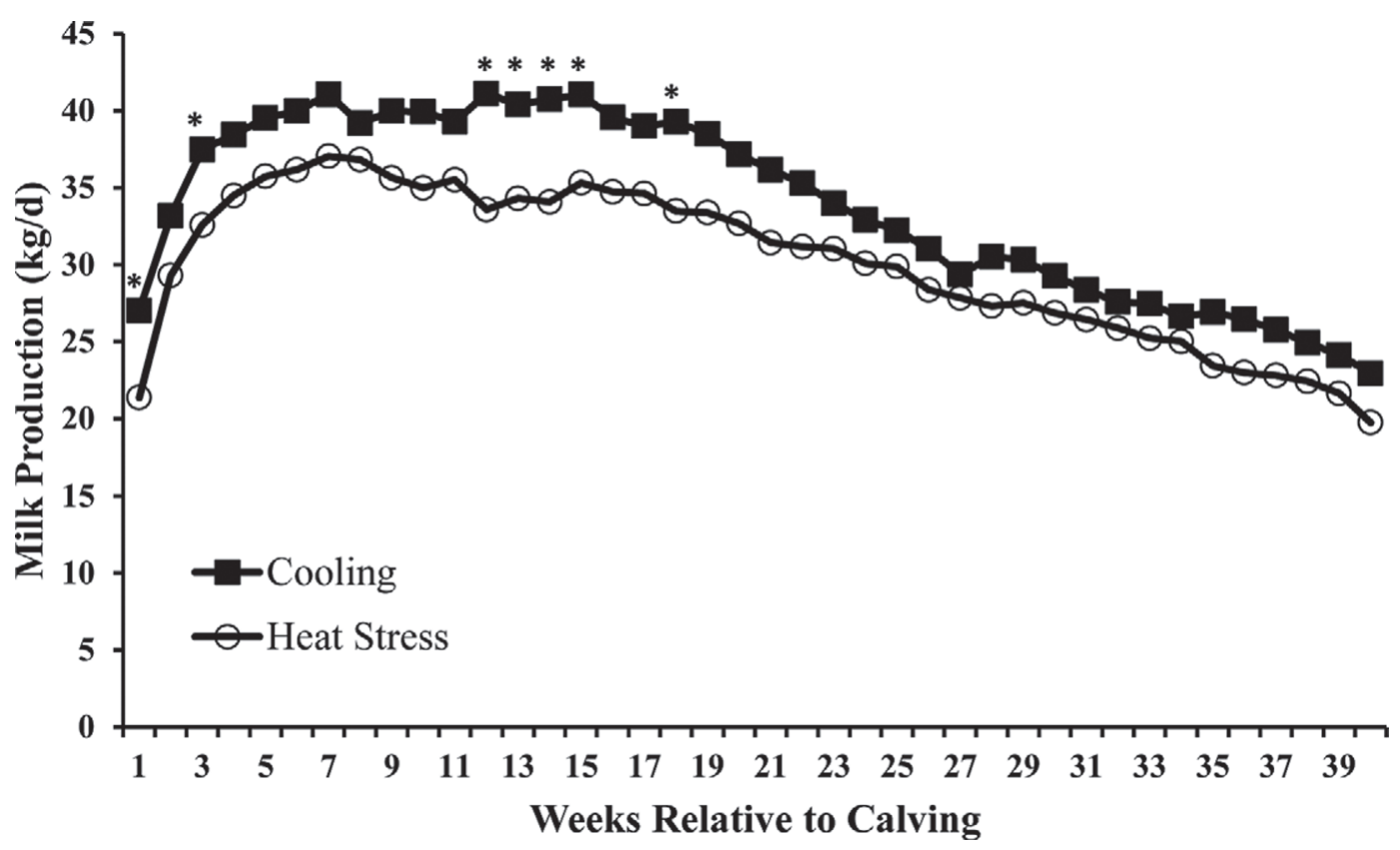

Figure 1. Effect of cooling $(\mathrm{n}=15)$ and heat stress $(\mathrm{n}=15)$ during the dry period on milk production in the subsequent lactation. After calving, cows from both treatments were housed under the same conditions. Cows exposed to cooling during the dry period tended to produce more milk compared with cows in heat stress up to $40 \mathrm{wk}$ in milk (33.8 $\pm 1.5 \mathrm{vs} .30 .0 \pm 1.5 \mathrm{~kg} / \mathrm{d}$, respectively; $P=0.10)$. Results are presented as LSM \pm SEM; asterisk $\left(^{*}\right)$ indicates that means differ $(P<0.05)$.

and $36 \mathrm{~h}$ relative to $12 \mathrm{~h}$ postinoculation. Overall milk composition was not affected during the challenge. Milk SCC was normally distributed and no changes were observed $(P=0.88)$ in milk SCC between challenged quarters, and milk protein and lactose did not change ( $P=0.51$ and $P=0.35$, respectively) throughout the challenge in infected quarters; however, milk fat decreased $(P<0.01)$ from 12 to $36 \mathrm{~h}$ compared with 0 h. Interestingly, we observed no changes between treatments in RT $(P<0.93)$, RR $(P<0.94)$ or milk production $(P<0.93)$ during the Strep. uberis IMI. Similar to the overall results, milk components such as lactose $(P$ $<0.37)$, protein $(P<0.98)$, fat $(P<0.64)$, and SCC $(P$
$<0.27)$ were not affected by treatment during the IMI. Moreover, no differences in SCC $(P<0.20)$, protein $(P<0.88)$, lactose $(P<0.69)$, or fat $(P<0.50)$ were observed between treated (i.e., Strep. uberis infusion) and control (i.e., sterile saline infusion) quarters.

Changes in hematological parameters during Strep. uberis IMI for cows exposed to either HT or CL are presented in Table 4. Independent of treatment, no changes were observed from 0 to $36 \mathrm{~h}$ postinoculation in white blood cell (WBC) count $(P=0.13)$, hemoglobin $(P=0.88)$, the number of neutrophils, lymphocytes, and monocytes $(P=0.99, P=0.51$, and $P$ $=0.36$, respectively), and percentages of neutrophils,

Table 3. Temperature-humidity index (THI) of the stall areas, dry period length, gestation length, rectal temperatures, and respiration rate of cows exposed to either heat stress $(\mathrm{n}=15)$ or cooling $(\mathrm{n}=15)$ during the dry period, and the same variables for the challenge subgroups ( $\mathrm{n}=5$ each for cooling and heat stress) in the Streptococcus uberis challenge

\begin{tabular}{lrrrr}
\hline Variable & Cooling & Heat stress & SEM & $P$-value \\
\hline Pen THI & 78.2 & 77.9 & 0.16 & - \\
Dry period length (d) & 39.8 & 34.8 & 1.39 & 0.01 \\
Gestation length (d) & 276.1 & 270.1 & 1.35 & $<0.01$ \\
Rectal temperature a.m. $\left({ }^{\circ} \mathrm{C}\right)$ & 38.3 & 38.6 & 0.04 & 0.01 \\
Rectal temperature p.m. $\left({ }^{\circ} \mathrm{C}\right)$ & 39.4 & 39.9 & 0.05 & $<0.01$ \\
Respiration rate (breath/min) & 45.0 & 78.7 & 2.31 & $<0.01$ \\
Challenge subgroups & & & & \\
Dry period length (d) & 37.0 & 32.4 & 1.93 & $<0.13$ \\
Gestation length (d) & 273.0 & 269.0 & 2.00 & $<0.09$ \\
Rectal temperature a.m. $\left({ }^{\circ} \mathrm{C}\right)$ & 38.4 & 38.6 & 0.03 & 0.01 \\
Rectal temperature p.m. $\left({ }^{\circ} \mathrm{C}\right)$ & 38.9 & 39.4 & 0.05 & $<0.01$ \\
Respiration rate (breath/min) & 47.2 & 79.0 & 2.70 & $<0.01$ \\
\hline
\end{tabular}




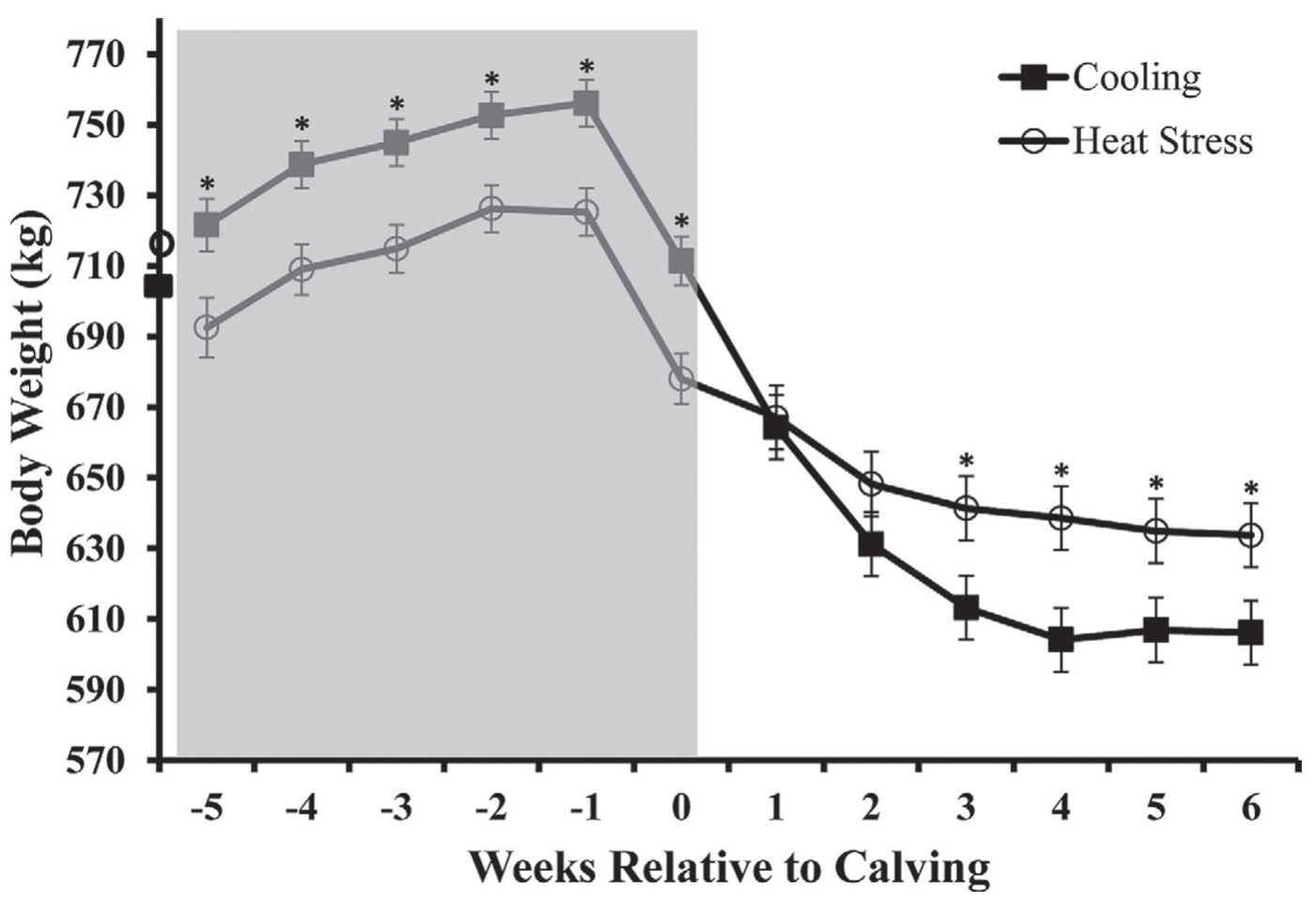

Figure 2. Effect of cooling $(\mathrm{CL} ; \mathrm{n}=15)$ and heat stress $(\mathrm{HT} ; \mathrm{n}=15)$ during the dry period on BW from dry off to $42 \mathrm{~d}$ relative to calving. Body weight did not differ between treatments at dry off ( $695.2 \pm 20.0$ vs. $721.0 \pm 20.0 \mathrm{~kg}$ for CL and HT cows, respectively; $P=0.37) ;$ however, compared with HT, the CL cows gained $42.4 \pm 6.0$ versus $13.4 \pm 6.1 \mathrm{~kg}$ before calving $(* P=0.01)$. No differences in BW were observed between treatments at calving $(711.42 \pm 6.9$ vs. $678.04 \pm 7.1 \mathrm{~kg}$ for CL and HT cows, respectively; $P=0.49)$; however, CL cows had a greater BW loss in early lactation compared with HT cows $\left(90.4 \pm 7.9\right.$ vs. $34.0 \pm 7.7 \mathrm{~kg}$ for CL and HT cows, respectively; $\left.{ }^{*} P=0.05\right)$. Data from prepartum and postpartum were analyzed separately, and BW at dry off and calving were used as covariates for the statistical analysis of BW during the pre- and postpartum periods, respectively, and are represented on the y-axis. Shading represents the prepartum period. Results are presented as $\mathrm{LSM} \pm \mathrm{SEM}$; asterisk $(*)$ indicates that means differ $(P<0.05)$.

lymphocytes, and monocytes $(P=0.52, P=0.66$, and $P=0.11$, respectively). However, red blood cell count and hematocrit decreased $(P=0.03$ and $P=0.02$, respectively) at $36 \mathrm{~h}$ postinoculation compared with $0 \mathrm{~h}$. Additionally, cooling cows during the dry period did not affect red blood cell count $(P=0.68)$, hematocrit $(P=0.83)$, hemoglobin $(P=0.81)$, number of lymphocytes and monocytes $(P=0.29$ and $P=0.26$, respectively), or percentages of neutrophils, lymphocytes, and monocytes $(P=0.39, P=0.35$, and $P=$ 0.69, respectively) during Strep. uberis IMI. However, relative to HT, CL cows had greater WBC count (11.7 \pm 1.33 vs. $7.45 \pm 1.33, P=0.05$; Table 4$)$ and a tendency to have a greater number of neutrophils (4.96 \pm 0.87 vs. $2.59 \pm 0.87, P=0.09$; Table 4 ) during Strep. uberis challenge.

\section{Gene Expression in Neutrophils}

Specific mRNA for $I L 1-\beta, T N F \alpha, I L 10, I L 8, I L 6$, and $T L R$ - 2 were expressed in bovine neutrophils during 0 , $12,18,24$, and 36 h relative to Strep. uberis IMI. No differences in expression of $I L 1-\beta$ (Figure $5 \mathrm{~A}$ ) and $T N F \alpha$
(Figure 5B) were observed between CL and HT during Strep. uberis IMI. In addition, overall blood neutrophil IL10 expression did not differ during Strep. uberis IMI between CL and HT cows; however, compared with CL, HT cows had a greater expression of IL10 $(3.17 \pm 0.15$ vs. $2.70 \pm 0.15 ; P=0.04)$ at $18 \mathrm{~h}$ relative to Strep. uberis IMI (Figure 6). Even though no differences were found between treatments in expression of IL8 (Figure $7 \mathrm{~A}$ ) and IL6 (Figure 7B), a significant increase in expression of both genes was observed in both treatments from 0 to $36 \mathrm{~h}$ relative to Strep. uberis IMI [4.12 \pm $0.58(0 \mathrm{~h})$ vs. $7.04 \pm 0.58(36 \mathrm{~h}) ; P<0.01$ (IL 8$) ; 10.83$ $\pm 0.60(0 \mathrm{~h})$ vs. $12.29 \pm 0.35(36 \mathrm{~h}) ; P=0.02$ (IL6)]. Furthermore, TLR-2 expression differed between treatments and over time relative to Strep. uberis IMI (Figure 8). Cows exposed to CL had greater overall TLR-2 expression during Strep. uberis IMI compared with HT cows $(4.51 \pm 0.08$ vs. $4.18 \pm 0.08 ; P=0.02)$. Additionally, a significant decrease in expression of $T L R-2$ was observed in both treatments from 0 to $36 \mathrm{~h}$ relative to Strep. uberis IMI $[4.60 \pm 0.13(0 \mathrm{~h})$ vs. $4.37 \pm 0.27(36$ h); $P=0.05$ (CL); $4.40 \pm 0.13(0$ h) vs. $3.76 \pm 0.27$ (36 h); $P=0.05(\mathrm{HT})]$. 


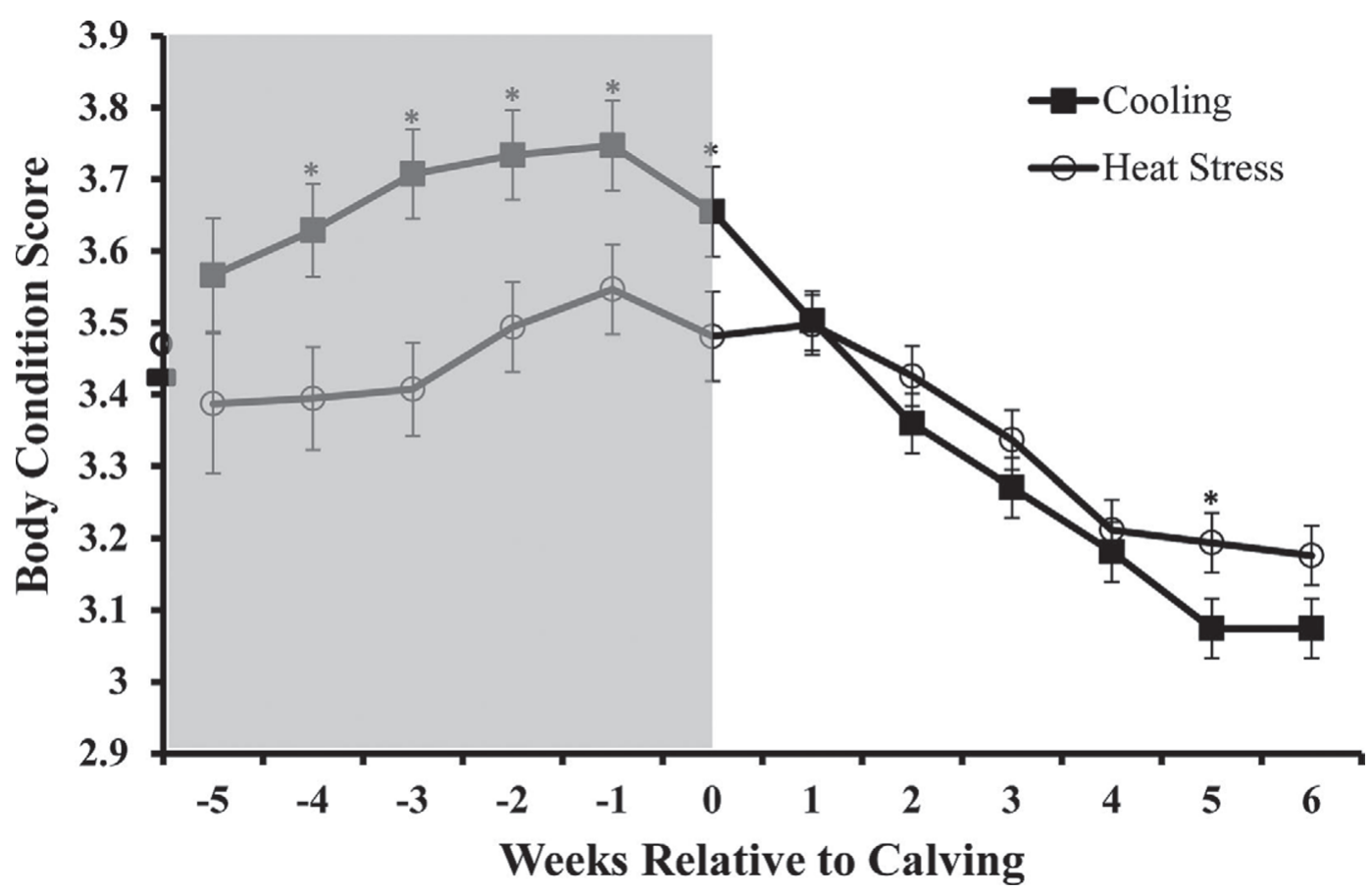

Figure 3. Effect of cooling $(\mathrm{CL} ; \mathrm{n}=15)$ and heat stress $(\mathrm{HT} ; \mathrm{n}=15)$ during the dry period on BCS from dry off to $42 \mathrm{~d}$ relative to calving. Treatments did not differ in BCS at dryoff (3.46 \pm 0.12 vs. $3.42 \pm 0.12 ; P=0.82$ for HT and CL, respectively); however, CL cows had a greater increase in BCS prepartum $(3.67 \pm 0.12$ vs. $3.45 \pm 0.12 ; * P=0.01)$ compared with HT cows. Additionally, CL cows had a greater decrease in BCS in early lactation $\left(3.24 \pm 0.02\right.$ vs. $\left.3.30 \pm 0.02 ;{ }^{*} P=0.10\right)$ compared with HT cows. No difference in BCS was observed between treatments at dry off $(P=0.82)$ or at calving $(P=0.31)$. Data from prepartum and postpartum were analyzed separately. BCS at dry off and calving were used as covariates for the statistical analysis of BCS during the pre- and postpartum period, respectively, and are represented on the y-axis. Shading represents the prepartum period. Results are presented as LSM \pm SEM; asterisk $(*)$ indicates that means differ $(P<0.05)$.

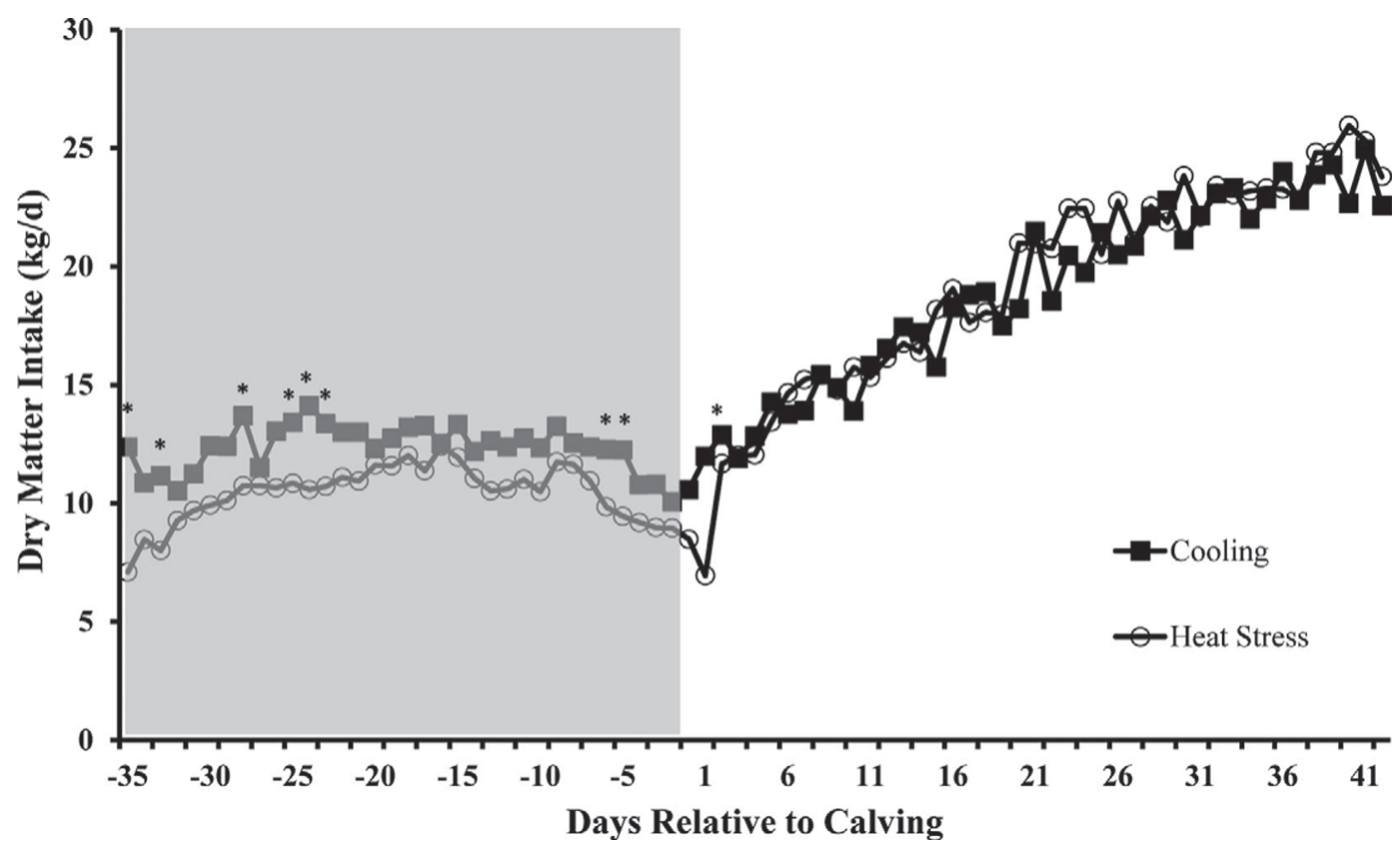

Figure 4. Effect of cooling $(\mathrm{CL} ; \mathrm{n}=15)$ and heat stress $(\mathrm{HT} ; \mathrm{n}=15)$ during the dry period on DMI from dry off to $42 \mathrm{~d}$ relative to calving. Relative to HT cows, CL cows consumed more feed prepartum $\left(12.3 \pm 0.46\right.$ vs. $10.4 \pm 0.46 \mathrm{~kg} / \mathrm{d}$; $\left.{ }^{*} P<0.01\right)$; however, no differences in DMI were observed between treatments during the postpartum period $(19.0 \pm 1.78$ vs. $19.4 \pm 1.77 \mathrm{~kg} / \mathrm{d} ; P=0.82)$. Data from prepartum and postpartum were analyzed separately. Shading represents the prepartum period. Results are presented as LSM \pm SEM; asterisk $(*)$ indicates that means differ $(P<0.05)$. 


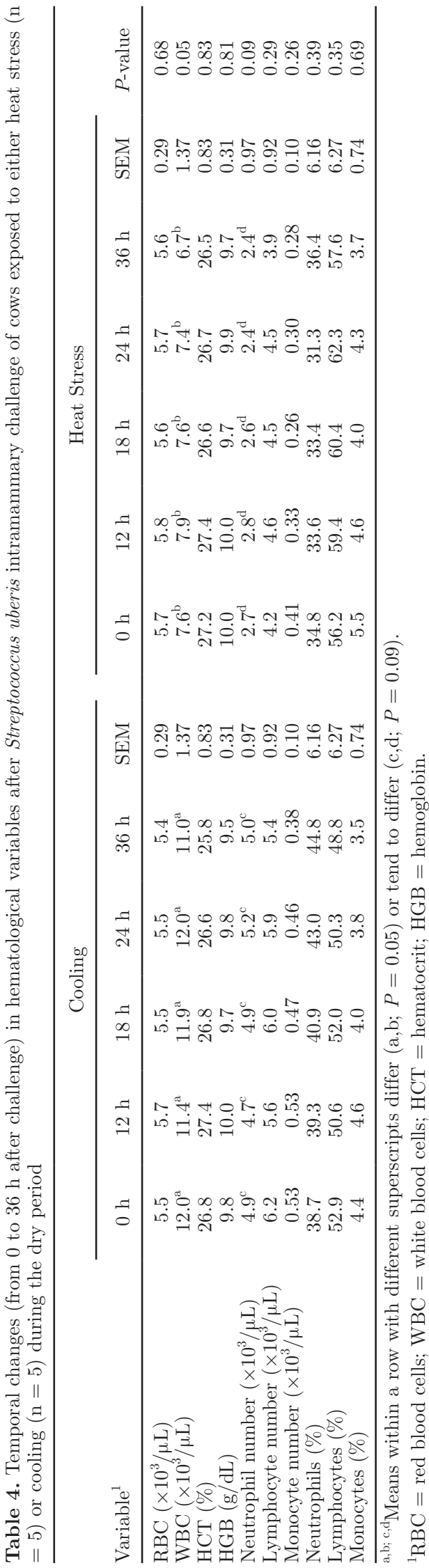

\section{DISCUSSION}

Despite the fact that THI measurements in the stall areas indicated that all cows exposed to both HT and CL treatments were under similar thermal environments during the dry period, we were able to show that the cooling system of fans and sprinklers was effective in alleviating heat stress in CL cows during the dry period,. Specifically, similar to previous studies (do Amaral et al., 2009; Tao et al., 2011), exposure of heatstressed cows to cooling during the dry period resulted in decreased RT and RR. Moreover, in agreement with previous reports (do Amaral et al., 2009; Tao et al., 2011), both dry period length and gestation length differed between CL and HT cows, such that HT cows had a significantly shorter dry period and gestation length compared with CL cows.

It is well documented that exposure to cows to heat stress during the dry period results in decreased subse-
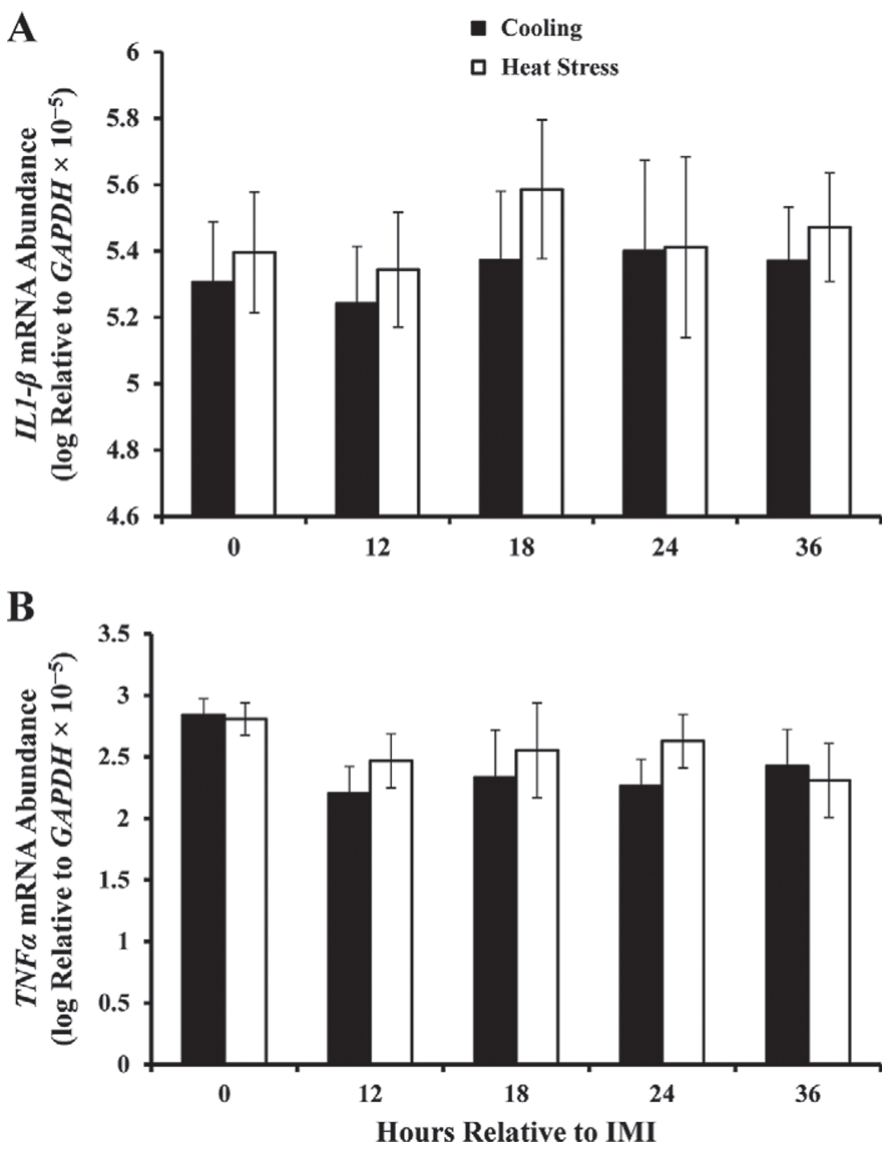

Figure 5. Effect of dry period cooling $(\mathrm{CL} ; \mathrm{n}=5)$ or heat stress $(\mathrm{HT} ; \mathrm{n}=5)$ on expression of $I L 1-\beta$ (panel A) and $T N F \alpha$ (panel B) mRNA in neutrophils isolated from blood at $0,12,18,24$, and $36 \mathrm{~h}$ relative to Strep. uberis IMI. No differences in expression of $I L 1-\beta$ and $T N F \alpha$ genes were observed between CL and HT during Strep. uberis IMI. Results are presented as LSM \pm SEM. 


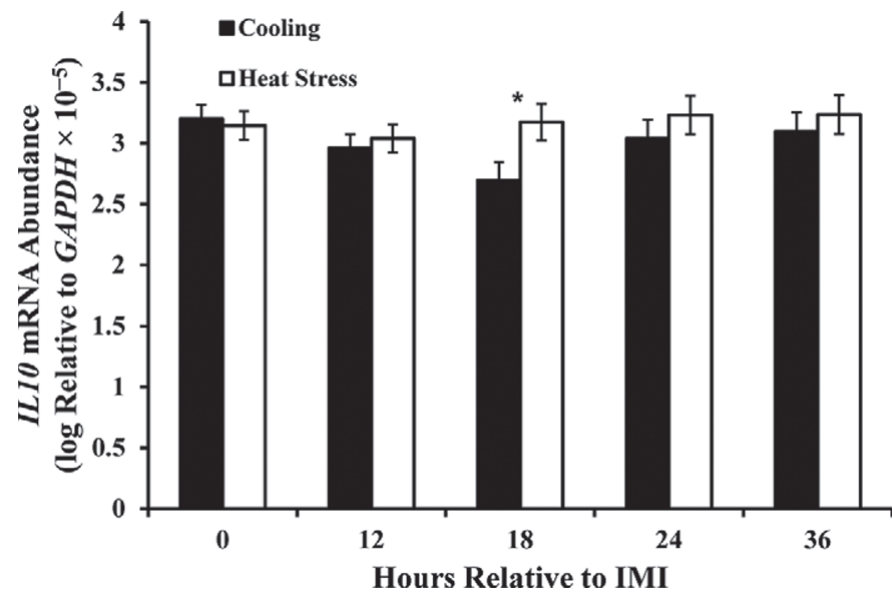

Figure 6. Effect of dry period cooling (CL; n $=5$ ) or heat stress $(\mathrm{HT} ; \mathrm{n}=5)$ on expression of IL10 mRNA in neutrophils isolated from blood at $0,12,18,24$, and $36 \mathrm{~h}$ relative to Strep. uberis IMI. Overall blood neutrophil IL10 expression did not differ during Strep. uberis IMI between CL and HT cows; however, compared with CL, HT cows had a greater expression of $I L 10(3.17 \pm 0.15$ vs. $2.70 \pm 0.15 ; P=$ $0.04)$ at $18 \mathrm{~h}$ relative to Strep. uberis IMI. Results are presented as $\mathrm{LSM} \pm \mathrm{SEM}$; asterisk $\left(^{*}\right)$ indicates that means differ $(P<0.05)$.

quent lactation milk yield (do Amaral et al., 2009, 2011; Tao et al., 2011). In the present study, the decrease in milk production caused by exposure to heat stress during the dry period was expected and consistent with previous reports (do Amaral et al., 2009; Tao et al., 2011). These results may be explained by the fact that prepartum exposure to HT results in impaired mammary gland development, as demonstrated by lower mammary epithelial cell proliferation during the dry period in HT compared with CL cows (Tao et al., 2011).

It has been previously reported (do Amaral et al., 2009; Tao et al., 2011) that heat abatement during the dry period results in an increase in DMI and BW. In accordance with previous studies, in the present study, cows exposed to cooling during the dry period gained more weight, consumed more feed, and had a greater increase in BCS before calving. Moreover, cows exposed to cooling during the dry period lost more weight during early lactation and tended to have a greater decrease in BCS during the early postpartum period compared with HT cows. These energetic responses in the CL cows are consistent with the greater milk yield observed relative to the HT cows.

In addition to the detrimental effects of dry period HT in the subsequent lactation milk yield, previous studies have shown that exposure of cows to heat stress during the dry period also decreases immune status (do Amaral et al., 2011). We have also observed a seasonal increase in the occurrence of postpartum diseases, with cows that are dry during hot months of the summer having greater incidence of mastitis, respiratory
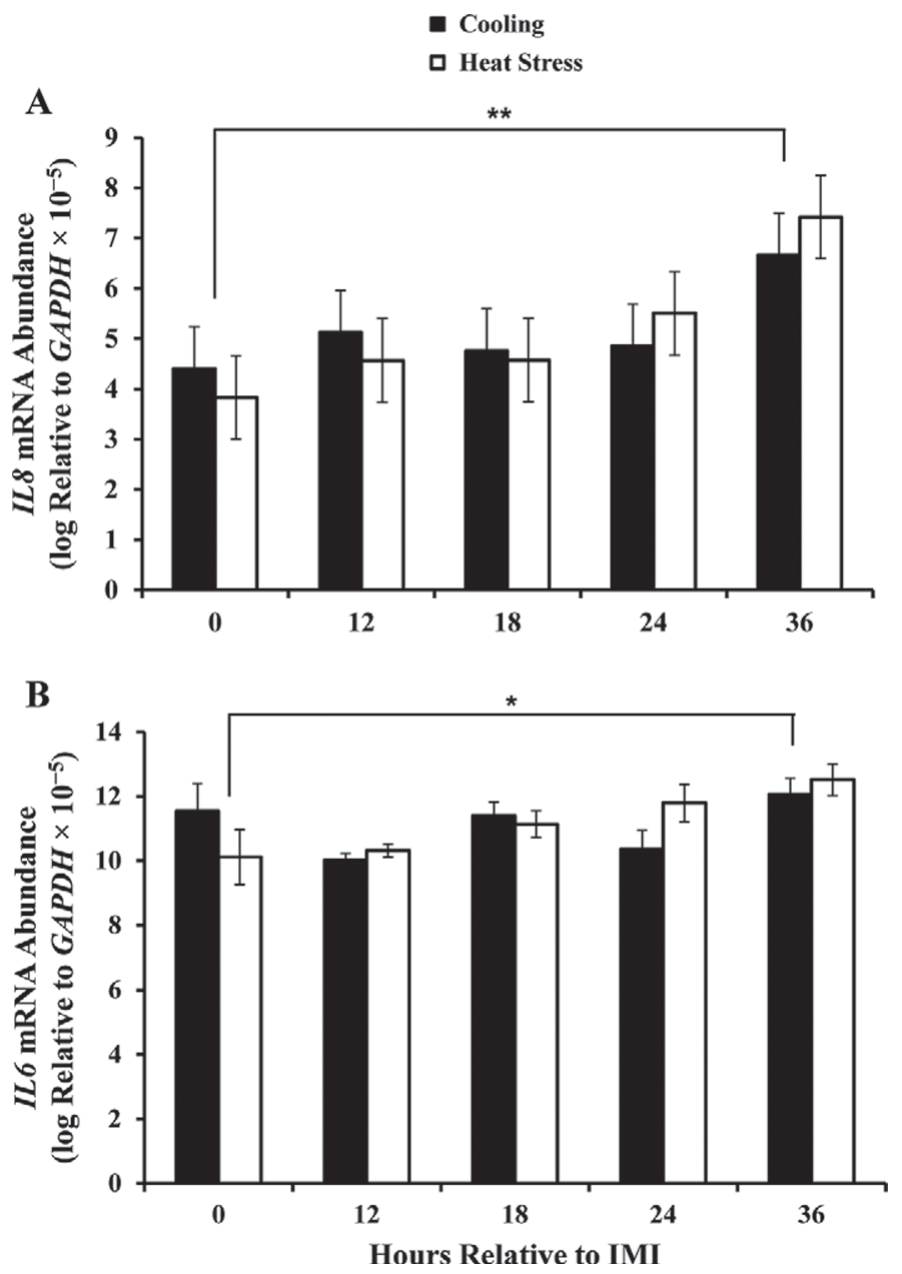

Figure 7. Effect of dry period cooling $(\mathrm{CL} ; \mathrm{n}=5)$ or heat stress $(\mathrm{HT} ; \mathrm{n}=5)$ on expression of $I L 8$ (panel A) and IL6 (panel B) mRNA in neutrophils isolated from blood at $0,12,18,24$, and $36 \mathrm{~h}$ relative to Strep. uberis IMI. No differences were observed between treatments in expression of $I L 8$ and $I L 6$, but a significant increase in expression of both genes was observed in both treatments from 0 to $36 \mathrm{~h}$ relative to Strep. uberis IMI $[4.12 \pm 0.58(0 \mathrm{~h})$ vs. $7.04 \pm 0.58(36 \mathrm{~h}) ; P<0.01$ (IL8); and $10.83 \pm 0.60(0 \mathrm{~h})$ vs. $12.29 \pm 0.35(36 \mathrm{~h}) ; P=0.02($ IL 6$)]$. Results are presented as LSM \pm SEM; asterisks indicate that means differ $\left(* P<0.05\right.$ and $\left.{ }^{* *} P<0.01\right)$.

disease, and retention of fetal membranes relative to herdmates that were dry during the winter (Thompson and Dahl, 2012). In the present study, we hypothesized that cooling cows during the dry period improves immune response to postpartum IMI to environmental pathogens such as Streptococcus uberis (Jackson et al., 2012). We decided to use a low dose of the pathogen because we did not want to overwhelm the cows, but we were still interested in testing the physiological capacity of the animal to respond to the insult under normal conditions instead of having a pharmacological type of response. Results showed that body temperature, milk production, and milk composition did not change be- 


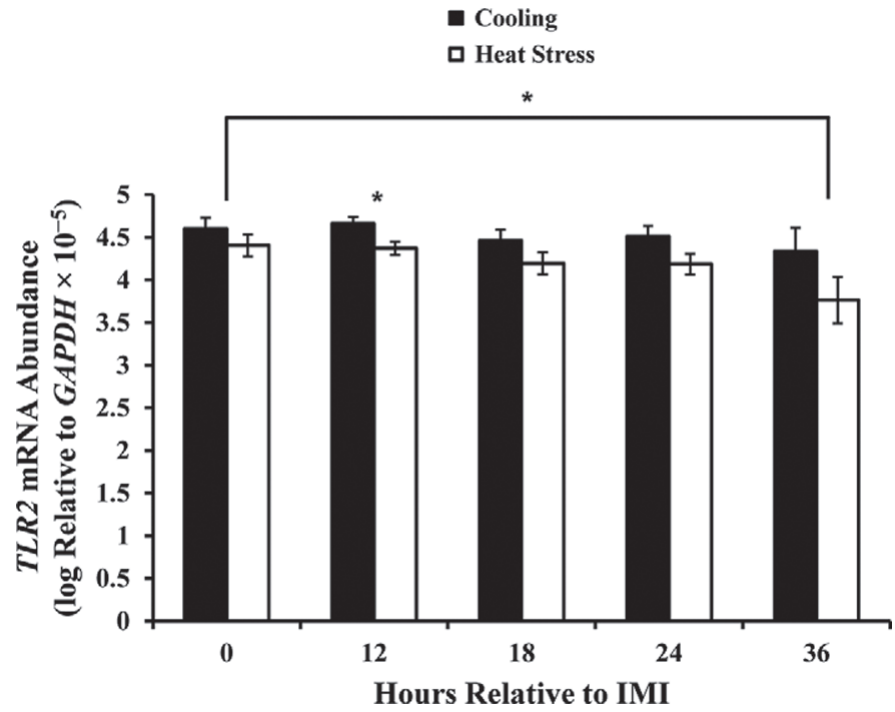

Figure 8. Effect of dry period cooling $(\mathrm{CL} ; \mathrm{n}=5)$ or heat stress $(\mathrm{HT} ; \mathrm{n}=5)$ on expression of TLR-2 mRNA in neutrophils isolated from blood during $0,12,18,24$, and 36 h relative to Strep. uberis IMI. Cows exposed to CL had greater overall TLR-2 expression during Strep. uberis IMI compared with HT cows $(4.51 \pm 0.08$ vs. $4.18 \pm 0.08$; $P=0.02$ ). Additionally, a significant decrease in expression of $T L R$ 2 was observed in both treatments from 0 to $36 \mathrm{~h}$ relative to Strep. uberis IMI $[4.60 \pm 0.13(0 \mathrm{~h})$ vs. $4.37 \pm 0.27(36 \mathrm{~h}) ; P=0.05(\mathrm{CL})$ and $4.40 \pm 0.13(0 \mathrm{~h})$ vs. $3.76 \pm 0.27(36 \mathrm{~h}) P=0.05(\mathrm{HT})]$. Results are presented as LSM $\pm \mathrm{SEM}$; asterisk $(*)$ indicates that means differ $(P<0.05)$

tween treatments during the Strep. uberis IMI. We observed that some of the values of the milk components were variable, too high, or both, which was the result of collecting the samples immediately after milking. Additionally, overall acute increases in body temperature and respiration rate were observed as well as a decrease in milk production. Similarly, Bannerman et al. (2004) observed an increase in rectal temperature and decrease in daily milk weight in cows undergoing intramammary challenge with Strep. uberis.

Additionally, in the present study, CL cows had greater WBC count and a greater number of neutrophils before and during the Strep. uberis challenge compared with HT cows, which suggests that cows exposed to cooling during the dry period have an improvement in immune function in early lactation compared with HT cows. Interestingly, do Amaral et al. (2011) reported that neutrophil oxidative burst and phagocytosis during early lactation were greater in cows exposed to cooling during the dry period compared with cows exposed to heat stress. These results suggest that heat stress abatement during the dry period improves innate immune response in dairy cows during the transition period. Whether the increase in oxidative burst or phagocytosis was related to changes in neutrophil number and thus capacity is unknown. In addition, we evaluated blood versus mammary gland neutrophils in the present study because cells that go to a tissue may be a poor index of capacity to respond to an infection, because they may be dead or deactivated, whereas circulating neutrophils are active and may be an alternative way to evaluate the capacity to respond to an infection at a specific tissue.

It has been reported that Strep. uberis IMI is associated with increases in pro- and antiinflammatory cytokines at both the gene and protein levels (Bannerman et al., 2004; Moyes et al., 2010). In the present study, we observed that specific RNA for IL1- $\beta, T N F \alpha, I L 10, I L 8$, $I L 6$, and $T L R-2$ were expressed in bovine neutrophils during 0,12, 18, 24, and $36 \mathrm{~h}$ relative to Strep. uberis IMI. The proinflammatory cytokines $I L 1-\beta$ and $T N F \alpha$, which are involved in both local and systemic inflammatory responses by promoting neutrophil recruitment to the site of infection (Dinarello, 1996), did not differ in expression between CL and HT during Strep. uberis IMI. Additionally, even though we observed no differences between treatments in gene expression of $I L 8$, which is a chemoattractant involved in recruitment of neutrophils to the site of infection, we did observe a significant increase in expression of $I L 8$ in circulating neutrophils of both treatments from 0 to $36 \mathrm{~h}$ relative to Strep. uberis IMI. The same was true for IL6 gene expression. Further, overall expression of blood neutrophil IL10, which is responsible for downregulation of proinflammatory cytokine production (Redpath et al., 2001), did not differ during Strep. uberis IMI between CL and HT cows; however, compared with CL, HT cows had greater expression of IL10 at $18 \mathrm{~h}$ relative to Strep. uberis IMI. In the present study, we evaluated the expression of $T L R$ - 2 in blood neutrophils during the Strep. uberis IMI. The TLR-2 gene codes for a toll-like receptor expressed in immune cells such as neutrophils and macrophages (Akira et al., 2001) and is involved in innate immune recognition of bacteria through recognition of peptidoglycan (Yoshimura et al., 1999) and lipoteichoic acid (Schröder et al., 2003) in gram-positive pathogens. Additionally, TLR-2 is one of the activators of the proinflammatory response and a link between innate and adaptive immune responses (Lee and Hwang, 2006). Interestingly, cows exposed to CL had greater overall TLR-2 expression in circulating neutrophils before and during Strep. uberis IMI compared with HT cows, which may indicate that CL cows have greater capacity to respond to IMI compared with HT cows. Additionally, a significant decrease in expression of TLR-2 was observed in both treatments from 0 to 36 h relative to Strep. uberis IMI.

\section{CONCLUSIONS}

In the present study, we observed that exposure of cows to heat stress during the dry period decreased 
subsequent lactation milk yield. In addition, CL cows had a greater WBC count and a greater number of neutrophils before challenge and maintained this difference during the Strep. uberis challenge compared with HT cows, which suggests that cows exposed to cooling during the dry period have an improved immune status in early lactation relative to HT cows. Moreover, qPCR analyses of genes expressed by neutrophils during the Strep. uberis IMI showed that CL cows have greater expression of IL10 compared with HT cows at $18 \mathrm{~h}$ relative to Strep. uberis IMI and a greater overall expression of $T L R$-2, which may indicate that CL cows have a greater capacity to respond to IMI compared with HT cows.

\section{REFERENCES}

Akira, S., K. Takeda, and T. Kaisho. 2001. Toll-like receptors: Critical proteins linking innate and acquired immunity. Nat Immunol. 8:675-680.

Bannerman, D. D., M. J. Paape, J. P. Goff, and K. Kimura. 2004 Innate immune response to intramammary infection with Serratia marcescens and Streptococcus uberis. Vet. Res. 35:681-700.

Collier, R. J., G. E. Dahl, and M. J. Vanbaale. 2006. Major advances associated with environmental effects on dairy cattle. J. Dairy Sci. 89:1244-1253.

Dikmen, S., E. Alava, E. Pontes, J. M. Fear, B. Y. Dikmen, T. A. Olson, and P. J. Hansen. 2008. Differences in thermoregulatory ability between slick-haired and wild-type lactating Holstein cows in response to acute heat stress. J. Dairy Sci. 91:3395-3402.

Dinarello, C. A. 1996. Cytokines as mediators in the pathogenesis of septic shock. Curr. Top. Microbiol. Immunol. 216:133-165.

do Amaral, B. C., E. E. Connor, S. Tao, M. J. Hayen, J. W. Bubolz, and G. E. Dahl. 2009. Heat-stress abatement during the dry period: Does cooling improve transition into lactation? J. Dairy Sci. 92:5988-5999.

do Amaral, B. C., E. E. Connor, S. Tao, M. J. Hayen, J. W. Bubolz, and G. E. Dahl. 2010. Heat stress abatement during the dry period influences prolactin signaling in lymphocytes. Domest. Anim. Endocrinol. 38:38-45.

do Amaral, B. C., E. E. Connor, S. Tao, M. J. Hayen, J. W. Bubolz, and G. E. Dahl. 2011. Heat stress abatement during the dry period influences metabolic gene expression and improves immune status in the transition period of dairy cows. J. Dairy Sci. 94:86-96.
Hahn, G. L. 1999. Dynamic responses of cattle to thermal heat loads J. Anim. Sci. 77(Suppl. 2):10-20.

Jackson, K. A., S. C. Nickerson, F. M. Kautz, and D. J. Hurley. 2012. Technical note: Development of a challenge model for Streptococcus uberis mastitis in dairy heifers. J. Dairy Sci. 95:7210-7213.

Jayarao, B. M., B. E. Gillespie, M. J. Lewis, H. H. Dowlen, and S. P. Oliver. 1999. Epidemiology of Streptococcus uberis intramammary infections in a dairy herd. Zentralbl. Veterinarmed. B 46:433-442.

Kadzere, C. T., M. R. Murphy, N. Silanikove, and E. Maltz. 2002 Heat stress in lactating dairy cows: A review. Livest. Prod. Sci. 77:59-91.

Lee, J. Y., and D. H. Hwang. 2006. The modulation of inflammatory gene expression by lipids: mediation through toll-like receptors. Mol. Cells 21:174-185.

Moyes, K. M., J. K. Drackley, D. E. Morin, S. L. Rodriguez-Zas, R. E. Everts, H. A. Lewin, and J. J. Loor. 2010. Mammary gene expression profiles during an intramammary challenge reveal potential mechanisms linking negative energy balance with impaired immune response. Physiol. Genomics 41:161-170.

Phuektes, P.. P. D. Mansell, R. S. Dyson, N. D. Hooper, J. S. Dick, and G. F. Browning. 2001. Molecular epidemiology of Streptococcus uberis isolates from dairy cows with mastitis. J. Clin. Microbiol. 39:1460-1466.

Redpath, S., P. Ghazal, and N. R. Gascoigne. 2001. Hijacking and exploitation of IL-10 by intracellular pathogens. Trends Microbiol. 9:86-92.

Schröder, N. W. S. Morath, C. Alexander, L. Hamann, T. Hartung, U. Zahringer, U. B. Weber, and R. R. Schumann. 2003. Lipoteichoic acid (LTA) of Streptococcus pneumonia and Staphylococcus aureus activates immune cells via Toll-like receptor (TLR)-2, lipopolysaccharide-binding protein (LBP), and CD14, whereas TLR-4 and MD-2are not involved. J. Biol. Chem. 278:15587-15594.

Tao, S., J. W. Bubolz, B. C. do Amaral, I. M. Thompson, M. J. Hayen, S. E. Johnson, and G. E. Dahl. 2011. Effect of heat stress during the dry period on mammary gland development. J. Dairy Sci. 94:5976-5986.

Thompson, I. M., and G. E. Dahl. 2012. Dry period seasonal effects on the subsequent lactation. Prof. Anim. Sci. 28:628-631.

Thompson, I. M., M. Osawa, J. W. Bubolz, Q. Yang, and G. E. Dahl. 2011. Bovine luteal prolactin receptor expression: Potential involvement in regulation of progesterone during the estrous cycle and pregnancy. J. Anim Sci. 89:1338-1346.

Vangroenweghe, F., I. Lamote, and C. Burvenich. 2005. Physiology of the periparturient period and its relation to severity of clinical mastitis. Domest. Anim. Endocrinol. 29:283-293.

Yoshimura, A., E. Lien, R. R. Ingalls, E. Tuomanen, R. Dziarski, and D. Golenbock. 1999. Cutting edge: Recognition of Gram-positive bacterial cell wall components by the innate immune system occurs via Toll-like receptor 2. J. Immunol. 163:1-5. 